\title{
Adequate Animal Protein Intake Maintains Normal Thyroid Antibody Levels in Pregnant Women With Mild lodine Deficiency
}

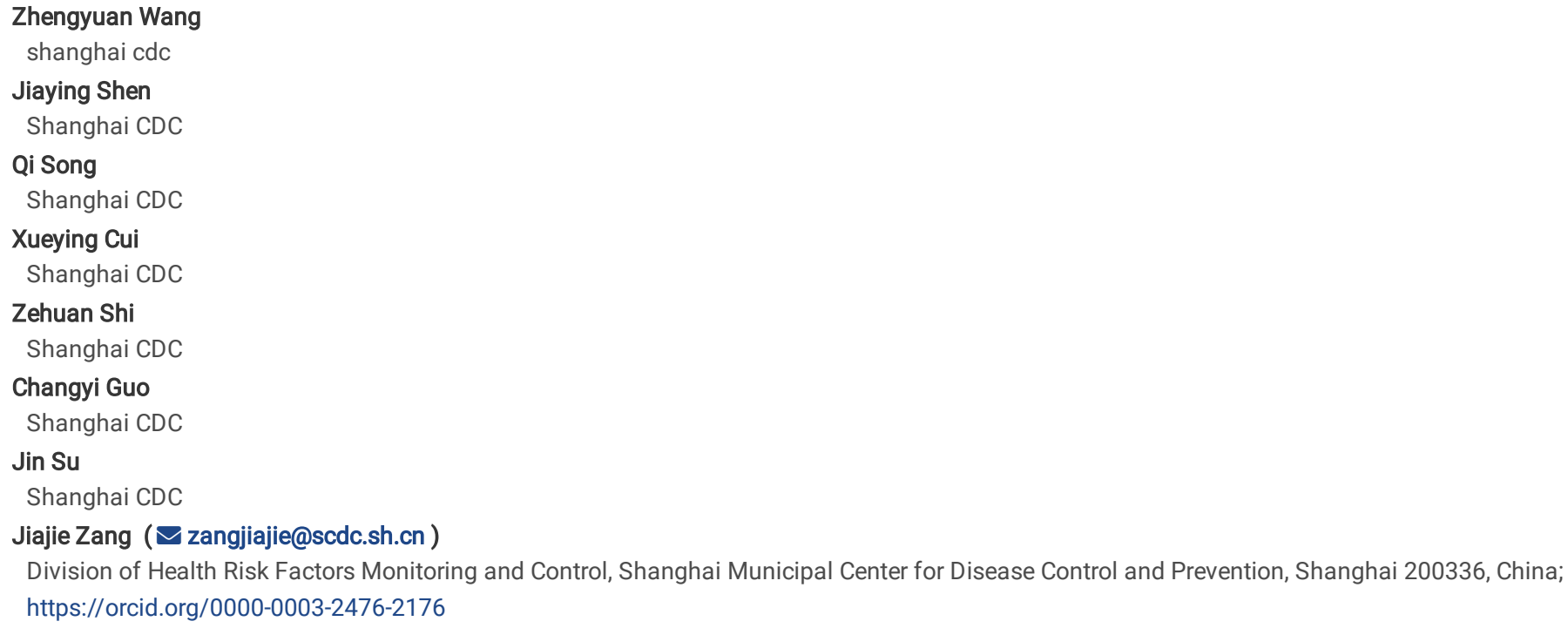

Research

Keywords: Thyroid peroxidase antibodies (TPO-Ab), thyroglobulin antibodies (TG-Ab), thyrotropin receptor antibodies (TR-Ab), animal protein, pregnant women Posted Date: January 13th, 2021

DOI: https://doi.org/10.21203/rs.3.rs-141454/v1

License: (9) (7) This work is licensed under a Creative Commons Attribution 4.0 International License. Read Full License 


\section{Abstract}

Background: Both of the iodine and animal protein may affect thyroid function. We explored the association between animal protein intake and thyroid antibody status in pregnant women after universal salt iodization.

Method: Pregnant women were enrolled by using a multistage, stratified random sampling method. 4,646 eligible participants were interviewed in person with questionnaires physical examination and thyroid antibody test.

Results: Only thyrotropin receptor antibodies (TR-Ab) positive rates were different among different animal protein intake groups. The median of urinary iodine concentration (UIC) in thyroid peroxidase antibodies (TPO-Ab) positive groups was higher than the negative group. The median of total protein intake, animal protein intake and UIC in TR-Ab positive group was higher than the negative group. The medians of total protein intake and UIC in TPO-Ab/TG-Ab/TR-Ab positive group were higher than the negative group. The above differences were statistically significant $(P<0.05)$. The multivariable logistic regression results showed that insufficient iodine had a negative correlation with TPO-Ab positive and TR-Ab positive $(\mathrm{P}<0.05)$. The middle third and top third animal protein intakes served as protective factors for TR-Ab (coefficient $=0.559,95 \% \mathrm{Cl}=0.415-0.752$; coefficient $=0.0 .406,95 \% \mathrm{Cl}=0.266-0.621$ ) and positive TPO$\mathrm{Ab} / \mathrm{TR}-\mathrm{Ab} / \mathrm{TG}-\mathrm{Ab}$ (coefficient $=0.817,95 \% \mathrm{Cl}=0.687-0.971$; coefficient $=0.805,95 \% \mathrm{Cl}=0.672-0.964)$.

Conclusions: Adequate animal protein intake protects against elevated anti-thyroid antibody levels in pregnant women with mild iodine deficiency.

\section{Introduction}

The autoimmune thyroid disease (AITD) represents the main cause of hypothyroidism during pregnancy, prevalence between 5 and $20 \%$ with an average of $7.8 \%[1,2]$. The AITD, which is 10 times more common in women than in men[3], is characterized by the rising of thyroid peroxidase antibodies (TPO-Ab), thyroglobulin antibodies (TG-Ab), and thyrotropin receptor antibodies (TR-Ab). According to a review, the environmental factors accounted for about $20-30 \%$ to the pathogenesis of AITD, nutritional status is one of the most important environmental factors [4].

Hormonal changes and metabolic stimulation affect the endocrine system and thyroid function during different stages of pregnancy[5, 6]. During the first trimester, maternal thyroxine is essential for proper fetal development. Pregnant women who are positive for thyroid antibodies are at significant risk for abortions and hypothyroidism during pregnancy[7]. Shanghai, which is the largest coastal city in China, has implemented the compulsory universal salt iodization since 1996. Even though the iodine nutritional status of the population is adequate, pregnant women are at risk for mild iodine deficiency[8, 9]. A study in endemic zone of a sub-Himalayan region reported that a negative correlation was observed between urinary iodine concentration (UIC) and anti-TPO $\mathrm{Ab}[10]$. And also, a cross-sectional study in 10 cities in China after mandatory universal salt iodization for 16 years showed that the prevalence of AITD has increased[11]. But data from a representative sample of pregnant women in Shanghai have not been published.

Dietary protein is closely related to thyroid function. Thyroxin is composed of amino acid derivatives[12], and protein depletion decreases the responsiveness of animals to the catabolic functions of the thyroid[13]. Besides, animal protein contains casein protein, which also has a close relationship with the thyroid to capture and use iodine[14]. Animal studies have shown that low iodine intake with high protein intake maintains thyroid hormone synthesis that protein deficiency may affect the function of immune cells and collectively cause autoimmune diseases[15, 16]. Based on nutritional surveys from 1982 to 2012 , the mean protein intake in Shanghai was always above $70.0 \mathrm{~g} / \mathrm{d}$ which was more than $65 \mathrm{~g} / \mathrm{d}$ of the recommended protein intake, and the proportion of protein from animal sources including milk increased from $15.5-46.8 \%[17,18]$

All of these indicated that high protein intake may be related to maintaining the thyroid health in Shanghai pregnant women. In this study, we intended to investigate the role of the different sources of protein intake on thyroid antibodies in pregnant women.

\section{Materials And Methods Study Sample}

Our data was collected from the iodine status in pregnancy and offspring health cohort (ISPOHC), conducted in April-October 2017. The formula for calculating complex sampling sample size was used to calculate the sample size required for analysis. At least 3,510 pregnant women were needed in the study. A multistage, stratified random sampling method was used to obtain a representative sample. In light of the sample size and the number of pregnant women in each administrative district in 2016, we determined the survey number in each administrative district. Each district was divided into five sections, a street was randomly selected from each section, and an equal number of pregnant women were selected from each section. Different gestational weeks were evenly represented in this study.

\section{Data Collection and diet evaluation}

Eligible subjects were interviewed face-to-face on demographics, pregnancy history, dietary habits, household condiments, physical activity and other information. Dietary habits were reported through a validated food frequency questionnaire (FFQ) [19] that consisted of 68 items that assessed the frequency and amount of foods consumed including dietary supplements over the past three months. The frequency of food intake was measured in four categories: "times per day", "times per week", "times per month", "times per 3 months". Similar foods were counted together. To estimate daily protein and iodine intake, we used food composition tables published for China [20].

A household condiment weighing method was used to collect data on cooking oil, salt, and soy sauce by documenting changes in the condiment inventory over one week. Additionally, the number of people who consumed the household condiments at each meal was recorded, and a household salt sample was 
collected for iodine concentration analysis. All data was reviewed by the local district project team and at least $5 \%$ of the data was reviewed by our project team.

According to the dietary recommendations intakes for Chinese 2013 edition, the estimated energy requirement and recommended nutrient intake (RNI) of protein were $1,800 \mathrm{kcal} / \mathrm{d}$ and $55 \mathrm{~g} / \mathrm{d}$ (early pregnancy), 2,100 kcal/d and $70 \mathrm{~g} / \mathrm{d}$ (middle pregnancy), and 2,250 kcal/d and $85 \mathrm{~g} / \mathrm{d}$ (late pregnancy),

respectively. The RNI of iodine was $230 \mu \mathrm{g} / \mathrm{L}$. [18]

\section{Urine sample collection, testing, and evaluation}

Subjects collected $5 \mathrm{~mL}$ urine in the morning, prior to food consumption. All samples were immediately stored at $4^{\circ} \mathrm{C}$, transported to the laboratory within $6 \mathrm{~h}$, where they were stored at under $80^{\circ} \mathrm{C}$. The laboratory complied with international standards ISO/IEC17025 and ISO/IEC 17020. Each urine sample was aciddigested (As3+-Ce4 + catalytic spectrophotometry) at designated test laboratory. Internal quality control samples for UIC were supplied by the Chinese National lodine Deficiency Disorders Reference Laboratory.

Iodine status was estimated using World Health Organization (WHO)/ United Nations Children's Fund (UNICEF)/ International Council for Control of lodine Deficiency Disorders (ICCIDD) criteria from 2007 and other published criteria as follows, severely insufficient (median UIC < 50 $\mu \mathrm{g} / \mathrm{L}$ ), moderately insufficient (median UIC $>50 \mu \mathrm{g} / \mathrm{L}$ and $<100 \mu \mathrm{g} / \mathrm{L}$ ), mildly insufficient (median UIC $>100 \mu \mathrm{g} / \mathrm{L}$ and $<150 \mu \mathrm{g} / \mathrm{L}$ ), adequate (median UIC $>150 \mu \mathrm{g} / \mathrm{L}$ and $<249 \mu \mathrm{g} / \mathrm{L}$ ), and excessive (median UIC $>250 \mu \mathrm{g} / \mathrm{L}$ )[21].

As the high within-person variability of a single spot urine, the WHO has limited the use and interpretation based on single spot urine per participant to the population median of a sufficiently large group (in general, > 30) [8]. In our study, the sampling error (95\% confidence interval (Cl) of the MUIC) was considered and calculated using bootstrapping. Pregnant women are divided into 80 units according to the district. When the upper cut-off level of MUIC's $95 \% \mathrm{Cl}$ in one unit was higher than $250 \mu \mathrm{g} / \mathrm{L}$, all pregnant women were assigned to the excessive iodine group in this unit. When the upper cut-off level was lower than $150 \mu \mathrm{g} / \mathrm{L}$, all pregnant women were assigned to the insufficient iodine group. The rest were assigned to the adequate iodine group.

\section{Thyroid antibody testing and evaluation}

Thyroid antibody data was obtained from tertiary hospitals or women's health centers. Due to the inconsistency of detection methods and reagents at different hospitals, only qualitative analyses were performed. Subjects with positive TPO-Ab/TG-Ab/TR-Ab had at least one positive thyroid antibody indicator. Otherwise, the subjects were TPO-Ab/TG-Ab /TR-Ab negative.

\section{Statistical Analysis}

All analyses were carried out using Excel (2010 Edition, Microsoft, Redmond, Washington, USA) and SPSS (version 21.0, IBM Corp., Armonk, NY, USA). Continuous and categorical variables were expressed as median (interquartile range) and percentage, respectively. Continuous variables were analyzed using one-way analysis of variance. We used the nonparametric Mann-Whitney and Kruskal-Wallis tests for data that were not normally distributed. The multivariable logistic regression (forward stepwise) was used for univariate analyses. The criterion for inclusion in the regression model was $p<0.05$, and the criterion for exclusion was $p>0.1$. Statistical significance was set at $\mathrm{P}<0.05$. Coefficient and $95 \%$ confidence intervals were calculated.

\section{Results}

\section{Energy, protein, and iodine intakes}

A total of 4646 qualified subjects were investigated and included in the analysis except those who were loss to follow-up, did not have complete recordings or had previous thyroid diseases. The median of energy, protein and iodine intake was $1985.6 \mathrm{kcal}, 80.1 \mathrm{~g}$ and $119.1 \mu \mathrm{g}$, respectively. Among the subjects, $62.3 \%$ exceeded protein RNI and 19.0\% exceeded iodine RNI (Table 1).

\section{Characteristics and thyroid antibodies stratified by animal protein}

The positive rate of TPO-Ab, TG-Ab, TR-Ab and TPO-Ab / TG-Ab b / TR-Ab was $10.40 \%, 9.43 \%, 8.47 \%$ and $20.56 \%$ in all subjects, respectively.

According to the animal protein intake, the subjects were divided into three tertiles: bottom third intake ( $<30.9 \mathrm{~g} / \mathrm{d})$, middle third intake (30.9-50.3 g/d), and top third intake ( $>50.3 \mathrm{~g} / \mathrm{d}$ ). In the pooled sample, there were significant differences in the constituent ratio of educational level and family income last year among the three animal protein intake groups $(\mathrm{P}<0.05)$. Just looking at the data, the proportions of better educational background and higher family income last year were higher in the middle third intake group. The median UIC in pregnant women was $139.3 \mu \mathrm{g} / \mathrm{L}$. There were no significant differences in age, median UIC, occupational status, and alcohol consumption among the three animal protein intake groups. The results of the different gestational stages are shown in Table 2.

The TR-Ab positive rate was significantly different in the pooled sample $(\mathrm{P}<0.05)$. Pairwise comparisons were performed among the three groups. The findings showed that the TR-Ab positive rate was higher in the bottom third intake group than in the other two groups $(\mathrm{P}<0.05)$. TPO-Ab positive rate was higher in the middle pregnancy in top third intake group than in the other groups $(P<0.05)$.

\section{Energy, protein, and iodine intakes and UIC in thyroid antibody positive and negative groups}

UIC and intakes of energy, total protein, animal protein (including milk protein), and iodine were compared between thyroid antibody positive and negative groups (table 3). The results showed that there was no significant difference in energy intake between both groups. In the pooled sample, the difference in UIC between TPO-Ab positive and negative groups was statistically significant $(P<0.05)$, and there was a statistically significant difference in total protein intake, 
animal protein intake, and UIC between TR-Ab positive and negative groups and in total protein intake and UIC between TPO-Ab/TG-Ab/TR-Ab positive and negative groups $(\mathrm{P}<0.05)$.

\section{Factors associated with positive thyroid antibodies}

Multivariable logistic regression analyses were conducted using general characteristics, animal protein intake (including milk protein), UIC, and other related factors as independent variables and thyroid antibodies as dependent variables (Table 4).

Compared to the bottom third animal protein intake, the middle third and the top third animal protein intake served as protective factors for positive TR-Ab (coefficient $=0.559,95 \% \mathrm{Cl}=0.415-0.752, \mathrm{P}=<0.001$; coefficient $=0.0 .406,95 \% \mathrm{Cl}=0.266-0.621, \mathrm{P}=<0.001$ ) and positive TPO-Ab/TR-Ab/TG-Ab (coefficient $=0.817,95 \% \mathrm{Cl}=0.687-0.971, \mathrm{P}=0.022$; coefficient $=0.805,95 \% \mathrm{Cl}=0.672-0.964, \mathrm{P}=0.018$ ), respectively. There was no significant association between animal protein intake and positive TPO-Ab or positive TG-Ab.

Compared to the low educational level, the senior high school and college level and Bachelor degree and above level served as protective factors for positive TR-Ab and TPO-Ab/TR-Ab/TG-Ab. Mental work compared with physical work served as risk factors for positive TPO-Ab, TG-Ab and TPO-Ab/TR-Ab/TG-Ab. The insufficient iodine group compared with adequate iodine group served as risk factors for positive TPO-Ab, TR-Ab and TPO-Ab/TR-Ab/TG-Ab. > 30\% energy from fat compared with $\leq 30 \%$ served as risk factors for positive TPO-Ab and TR-Ab. The above differences were statistically significant, $\mathrm{P}<0.05$.

\section{Discussion}

Dietary protein plays an essential role in thyroid function. The median total protein and animal protein intake of the subjects were $80.1 \mathrm{~g} / \mathrm{d}$ and $38.9 \mathrm{~g} / \mathrm{d}$. The protein intake exceeded protein RNI in $62.3 \%$ of the subjects, consistent with recent other population data from the Shanghai survey[22]. The positive rate of TPO-Ab, TG-Ab, and TR-Ab was $10.40 \%, 9.43 \%$, and $8.47 \%$, respectively. Studies have shown that TPO-Ab positivity is common in women of childbearing age with a prevalence ranging between $5.1 \%$ and $12.4 \%$ [7], consistent with the result of this study. Surveillance in iodine adequate areas of China showed an isolated TG-Ab positive rate of about $7 \%$ in pregnant women[23].

Pregnant women had a median UIC of $139.3 \mu \mathrm{g} / \mathrm{L}$, which was slightly below the recommended median UIC range $(150-249 \mu \mathrm{g} / \mathrm{L})$ established by WHO/UNICEF/ICCIDD for pregnant women. The insufficient iodine group had high rates of positive TPO-Ab, TR-Ab, and TPO-Ab/TG-Ab/TR-Ab, which is in accordance with the findings of Laurberg who reported that mild iodine deficiency might increase thyroid antibody levels[24]. Even though the iodine intake among Shanghai pregnant women is insufficient, their animal protein intake is adequate. The Qinghai Preventive Institute of Endemic Diseases in China conducted an animal experiment that assessed thyroid function in mice when they had a low daily intake of iodine and a relatively high intake of protein. The findings revealed that thyroid glands of mice were able to maintain basic function and produce thyroid hormones[15]. Even though adequate iodine intake is important, intake of high-quality protein might effectively prevent the occurrence and development of thyroid disorders[15].

Our findings have shown that adequate animal protein intake is a protective factor for TR-Ab and TPO-Ab/TR-Ab/TG-Ab positivity. Unfortunately, we did not observe statistical association between animal protein intake and TPO-Ab or TG-Ab positivity, probably due to the relative sensitivity of TPO-Ab and TG-Ab to dietary fat. In our study, the percentage of energy from fat $>30 \%$ is a risk factor for TPO-Ab and TG-Ab positivity. Researchers, who investigated the relationship between diet and thyroid function in 97,000 people from the USA and Canada, reported that vegan diets are associated with a lower risk[25, 26]. A study that evaluated the relationship between dietary patterns and thyroid antibodies revealed that the frequent consumption of animal fat is associated with positive TPO-Ab and/or positive $\mathrm{Tg}$-Ab[27]. There is a positive association between saturated fatty acids from animal fat and high-sensitivity $\mathrm{C}$-reactive protein levels, which may stimulate inflammatory responses[28] and induce AITD.

The different results among TPO-Ab, TG-Ab, and TR-Ab may be attributed to gestational stage and diverse antigen location. Pregnant women have lower levels of thyroid antibodies than non-pregnant women, due to the synthesis of maternal regulatory T-cells that maintain a state of tolerance to fetal alloantigen to prevent rejection of the fetus[29]. This pattern of antibody behavior can show a noticeable fall in levels of antibody against TR-Ab[30]. Additionally, antigen location is different among the three antibodies. TR-Ab is extracellular, and cells have access to antigens without tissue destruction, which suggests that it tends to be earlier affected. However, it is also more likely to be influenced by more confounders like other inflammatory parameters in serum. TPO-Ab is intracellular and TG-Ab is intrafollicular, only after thyrocyte destruction can antigen be accessed; as a result, TPO-Ab may relatively more steadily be affected by animal protein[31].

High educational level had a protective effect against thyroid antibody positivity, while mental work increased the risk. Pregnant women with high educational level are likely to have higher health literacy and healthier dietary habits[32]. Additionally, job engagement might empower pregnant women to make better decisions on their dietary habits and healthcare[33], which positively affects their well-being. Mental workload contributes to fatigue condition and stressful emotion[34], which could be a risk factor for AITD[35].

To the best of our knowledge, this is the first study with a representative sample in pregnant women that examined the association between animal protein intake and thyroid antibodies. Our study had some limitations. First, even though the thyroid antibody data was acquired from hospitals and women's health centers, the detection methods and instruments were inconsistent. Therefore, we could not perform a quantitative analysis of thyroid antibodies. Second, due to complex food composition data, there are probably some unknown confounders that may have affected the results.

\section{Conclusion}

In conclusion, adequate animal protein intake is a protective factor for thyroid antibody positivity, especially in pregnant women with iodine deficiency. Increased energy intake from fat increases the risk for positive thyroid antibodies. Therefore, pregnant women should limit their fat intake while consuming 
adequate amounts of animal protein. lodine supplements are recommended for pregnant women with iodine deficiency.

\section{Abbreviations}

AITD

Autoimmune thyroid disease; FFQ:Food frequency questionnaire; ICCIDD:International Council for Control of lodine Deficiency Disorders; ISPOHC:Iodine status in pregnancy and offspring health cohort; RNI:recommended nutrient intake; TG-Ab:Thyroglobulin antibodies; TPO-Ab:Thyroid peroxidase antibodies; TRAb:Thyrotropin receptor antibodies; UIC:Urinary iodine concentration; UNICEF:United Nations Children's Fund; WHO:World Health Organization.

\section{Declarations}

\section{Ethics approval and consent to participate}

This study was conducted according to the guidelines laid down in the Declaration of Helsinki and all procedures involving human subjects were approved by the Shanghai Municipal Centre for Disease Control and Prevention (CDC) (NO.2016-5). Written informed consent was obtained from all participants.

\section{Consent for publication}

Not applicable.

\section{Availability of data and materials}

Please contact author for data requests.

\section{Competing interests}

All authors declare that we have no known competing financial interests or personal relationships that could have appeared to influence the work reported in this paper.

\section{Funding}

The study was financially supported by key disciplines in the three-year Plan of Shanghai municipal public health system (2020-2022) (GWV-10.1-XK11), academic leader in the three-year Plan of Shanghai municipal public health system (2020-2022) (GWV-10.2-XD18) and outstanding young Talents in the threeyear Plan of Shanghai municipal public health system (2020-2022) (GWV-10.3-YQ22) and Top Young Talents in Shanghai (No. 2020-8). They have no role in the design, analysis or writing of this article. This research received no specific grant from any funding agency, commercial or not-for-profit sector.

\section{Authors' contributions}

Data curation, ZW and JZ; Funding acquisition, ZW and JZ; Investigation, ZW, XC, QS, ZS and JZ; Project administration, ZW, CG, JS and JZ; Supervision, CG and JS; Writing - original draft, ZW and JS; Writing - review \& editing, ZW, JS, CG , JS and JZ. All authors read and approved the final manuscript.

\section{Acknowledgements}

We are grateful to the pregnant women who participate in this study and to the healthcare professionals from the CDC of the 16 districts in Shanghai.

\section{Author details}

${ }^{1}$ Division of Health Risk Factors Monitoring and Control, Shanghai Municipal Center for Disease Control and Prevention, Shanghai 200336, China. ${ }^{2}$ General Office, Shanghai Municipal Center for Disease Control and Prevention, Shanghai 200336, China.

\section{References}

1. Krassas G, Karras SN, Pontikides N. (2015)Thyroid diseases during pregnancy: a number of important issues. Hormones (Athens), 14: 59-69.

2. Konrade I, Kalere I, Strele I, et al. (2015) lodine deficiency during pregnancy: a national cross-sectional survey in Latvia. Public Health Nutr, 18: $2990-2997$.

3. Li H, Li J. (2015) Thyroid disorders in women. Minerva Med, 106: 109-114.

4. Wiersinga WM. (2016) Clinical Relevance of Environmental Factors in the Pathogenesis of Autoimmune Thyroid Disease. Endocrinol Metab (Seoul) , 31: 213-222.

5. Moreno-Reyes R, Glinoer D, Van Oyen H, et al. (2013) High prevalence of thyroid disorders in pregnant women in a mildly iodine-deficient country: a population-based study. J Clin Endocrinol Metab, 98: 3694-3701.

6. Glinoer D. (1997) The regulation of thyroid function in pregnancy: pathways of endocrine adaptation from physiology to pathology. Endocr Rev, 18: 404433.

7. Springer D, Jiskra J, Limanova Z, et al. (2017) Thyroid in pregnancy: From physiology to screening. Crit Rev Clin Lab Sci, 54: $102-116$.

8. Wang Z, Wu Y, Shi Z, et al. (2020) Association of iodine-related knowledge, attitudes and behaviours with urinary iodine excretion in pregnant women with mild iodine deficiency. J Hum Nutr Diet. 18. doi: 10.1111/jhn.12837. 
9. Wang Z, Zang J, Shi Z, et al. (2019) lodine status of 8 to 10 years old children within 20 years following compulsory salt iodization policy in Shanghai, China. Nutr J, 18:63. doi: 10.1186/s12937-019-0491-x.

10. Ganie MA, Charoo BA, Sahar T, et al. (2020) Thyroid Function, Urinary lodine, and Thyroid Antibody Status Among the Tribal Population of Kashmir Valley: Data From Endemic Zone of a Sub-Himalayan Region. Front Public Health. 28;8:555840.

11. Shan Z, Chen L, Lian, X, et al. (2016) lodine Status and Prevalence of Thyroid Disorders After Introduction of Mandatory Universal Salt lodization for 16 Years in China: A Cross-Sectional Study in 10 Cities. Thyroid,26:1125-11

12. Mendoza A, Hollenberg AN. (2017) New insights into thyroid hormone action. Pharmacol Ther, 173, 135-145.

13. Palkowska-Gozdzik E, Lachowicz K, Rosolowska-Huszcz D. (2017) Effects of dietary protein on thyroid axis activity. Nutrients, 10: 5 . doi: 10.3390/nu10010005.

14. J. G. Eales, D. L. MacLatchy, D. A. Higgs, et al. (1992) The influence of dietary protein and caloric content on thyroid function and hepatic thyroxine 5'monodeiodinase activity in rainbow trout. Oncorhynchus mykiss,70, 1526-1535.

15. Xiuli Z, Chuanlong X, Xianya M, et al. (2006) Effect of protein on thyroid hormone in mice with low iodine. Qinghai medical journal, 36:12-14.

16. Lopez Plaza B, Bermejo Lopez LM. (2017) Nutrition and immune system disorders. Nutr Hosp, 34(Suppl 4): 68-71.

17. Huang CH, Lu Y, Zang JJ, et al. (2016) Nutrition Transition Among Residents in Shanghai: Data Analysis Based on National Nutrition and Health Surveys in 1982-2012. J Environ Occup Med, 33: 845-848

18. Chinese nutrition (2016) Dietary guidelines for Chinese residents. People's Medical Publishing House, 2016, Beijing.

19. Jun S, Jiajie Z, Hongmei T, et al. (2016) Relative validity of food frequency questionnaire for estimating dietary nutrients intake Journal of Hygiene Research. Wei Sheng Yan Jiu, 45: 743-748.

20. Yang Y. (2009) China food Composition. Peking University Medical Press, Beijing.

21. Secretariat WHO, Andersson M, de Benoist B, et al. (2007) Prevention and control of iodine deficiency in pregnant and lactating women and in children less than 2-years-old: conclusions and recommendations of the Technical Consultation. Public Health Nutr, 10: 1606 -1611.

22. Zhu Z, Wu C, Luo B, et al. (2019) The Dietary Intake and Its Features across Four Seasons in the Metropolis of China. J Nutr Sci Vitaminol (Tokyo), 65:5259.

23. Zhang HY, Teng XC, Shan ZY, et al. (2019) Association between iron deficiency and prevalence of thyroid autoimmunity in pregnant and non-pregnant women of childbearing age: a cross-sectional study. Chin Med J (Engl) , 132: 2143-2149.

24. Laurberg P, Cerqueira C, Ovesen L, et al. (2010) lodine intake as a determinant of thyroid disorders in populations. Best Pract Res Clin Endocrinol Metab, 24: 13-27.

25. Tonstad S, Nathan E, Oda K, et al. (2015) Prevalence of hyperthyroidism according to type of vegetarian diet. Public Health Nutr,18: $1482-1487$.

26. Tonstad S, Nathan E, Oda K, et al. (2013) Vegan diets and hypothyroidism. Nutrients, 5: 4642-4652.

27. Matana A, Torlak V, Brdar D, et al.(2017) Dietary factors associated with plasma thyroid peroxidase and thyroglobulin antibodies. Nutrients, 9: doi: 10.3390/nu9111186.

28. Pattison DJ, Symmons DP, Lunt M, et al. (2004) Dietary risk factors for the development of inflammatory polyarthritis: evidence for a role of high level of red meat consumption. Arthritis Rheum, 50: 3804-3812.

29. Weetman AP. (2010) Immunity, thyroid function and pregnancy: molecular mechanisms. Nat Rev Endocrinol, 6: 311-318.

30. Effraimidis G, Wiersinga WM. (2014) Mechanisms in endocrinology: autoimmune thyroid disease: old and new players. Eur J Endocrinol, 170 : R241-252.

31. Frohlich E, Wahl R. (2017) Thyroid autoimmunity: role of anti-thyroid antibodies in thyroid and extra-thyroidal diseases. Front Immuno, 8:

32. Kastro S, Demissie T, Yohannes B. (2018) Low birth weight among term newborns in Wolaita Sodo town, South Ethiopia: a facility based cross-sectional study. BMC Pregnancy Childbirth, 18:

33. Redman K, Ruffman T, Fitzgerald P, et al. (2016) lodine deficiency and the brain: effects and mechanisms. Crit Rev Food Sci Nutr, 56: $2695-2713$.

34. Quendler E, Trieb K, Nimmerichter. (2017) A validation of automated detection of physical and mental stress during work in a Huhnermobil 225. Ann Agric Environ Med, 24: 329-331.

35. Mizokami T, Wu Li A, El-Kaissi S, Wall JR. (2004) Stress and thyroid autoimmunity. Thyroid, 14: 1047-1055.

\section{Tables}

Table 1. Distributions of energy, different food sources of protein and iodine in pregnant women stratified by pregnancy stage 


\begin{tabular}{|c|c|c|c|c|c|c|c|c|}
\hline $\begin{array}{l}\text { Pregnancy } \\
\text { stage }\end{array}$ & $\mathrm{N}$ & Quantile & $\begin{array}{l}\text { Energy } \\
(\mathrm{kcal})\end{array}$ & $\begin{array}{l}\text { Total } \\
\text { protein }(\mathrm{g})\end{array}$ & $\begin{array}{l}\text { Animal protein (including milk } \\
\text { protein, g) }\end{array}$ & $\begin{array}{l}\text { Animal protein (no milk } \\
\text { protein) }(\mathrm{g})\end{array}$ & $\begin{array}{l}\text { Milk } \\
\text { protein }(\mathrm{g})\end{array}$ & $\begin{array}{l}\text { lodine } \\
(\mu \mathrm{g})\end{array}$ \\
\hline \multirow[t]{7}{*}{ Pooled } & \multirow[t]{7}{*}{4646} & P20 & 1430.1 & 55.7 & 24.5 & 20.3 & 1.4 & 47.4 \\
\hline & & P33.3 & 1683.6 & 66.6 & 30.9 & 26.3 & 2.8 & 78.7 \\
\hline & & P40 & 1809.3 & 71.8 & 33.9 & 28.9 & 3.9 & 94.2 \\
\hline & & P50 & 1985.6 & 80.1 & 38.9 & 33.8 & 5.5 & 119.1 \\
\hline & & P60 & 2194.7 & 89.9 & 44.8 & 39.5 & 5.5 & 146.0 \\
\hline & & P66.7 & 2371.2 & 99.0 & 50.3 & 44.6 & 5.5 & 162.9 \\
\hline & & P80 & 2846.7 & 124.1 & 64.6 & 59.5 & 6.9 & 226.0 \\
\hline \multirow{7}{*}{$\begin{array}{l}\text { Early } \\
\text { pregnancy }\end{array}$} & \multirow[t]{7}{*}{1686} & P20 & 1376.3 & 52.9 & 22.6 & 18.6 & 1.2 & 46.0 \\
\hline & & P33.3 & 1620.7 & 63.0 & 28.8 & 24.5 & 2.8 & 74.3 \\
\hline & & P40 & 1735.0 & 68.3 & 31.4 & 27.3 & 3.1 & 88.6 \\
\hline & & P50 & 1897.8 & 75.2 & 36.1 & 31.8 & 4.9 & 114.7 \\
\hline & & P60 & 2093.6 & 83.7 & 41.4 & 36.6 & 5.5 & 141.3 \\
\hline & & P66.7 & 2230.0 & 92.5 & 45.5 & 40.7 & 5.5 & 160.2 \\
\hline & & P80 & 2729.9 & 116.1 & 60.8 & 55.7 & 6.9 & 222.4 \\
\hline \multirow{7}{*}{$\begin{array}{l}\text { Middle } \\
\text { pregnancy }\end{array}$} & \multirow[t]{7}{*}{1671} & P20 & 1451.5 & 57.7 & 24.5 & 20.5 & 1.2 & 47.5 \\
\hline & & P33.3 & 1719.8 & 67.2 & 30.6 & 26.2 & 2.8 & 80.3 \\
\hline & & P40 & 1850.5 & 72.8 & 34.0 & 28.5 & 3.7 & 97.1 \\
\hline & & P50 & 2037.5 & 81.6 & 38.9 & 33.8 & 5.5 & 124.0 \\
\hline & & P60 & 2260.5 & 91.1 & 45.4 & 39.4 & 5.5 & 149.9 \\
\hline & & P66.7 & 2442.9 & 100.3 & 51.3 & 44.8 & 5.5 & 165.9 \\
\hline & & P80 & 2863.5 & 124.9 & 64.6 & 59.6 & 6.9 & 229.9 \\
\hline \multirow{7}{*}{$\begin{array}{l}\text { Late } \\
\text { pregnancy }\end{array}$} & \multirow[t]{7}{*}{1389} & P20 & 1469.1 & 58.5 & 27.2 & 22.2 & 1.6 & 50.0 \\
\hline & & P33.3 & 1716.3 & 70.0 & 33.7 & 28.3 & 3.4 & 84.6 \\
\hline & & P40 & 1851.3 & 75.6 & 37.0 & 31.7 & 4.1 & 97.7 \\
\hline & & P50 & 2049.7 & 84.8 & 42.2 & 37.0 & 5.5 & 119.1 \\
\hline & & P60 & 2272.0 & 95.6 & 48.7 & 43.2 & 5.5 & 146.5 \\
\hline & & P66.7 & 2450.6 & 105.0 & 55.7 & 48.3 & 6.4 & 163.7 \\
\hline & & P80 & 2960.3 & 130.7 & 68.0 & 62.8 & 6.9 & 222.6 \\
\hline
\end{tabular}

*The estimated energy requirement and recommended nutrient intake (RNI) of protein were 1,800 kcal/d and $55 \mathrm{~g} / \mathrm{d}$ (early pregnancy), 2,100 kcal/d and 70 $\mathrm{g} / \mathrm{d}$ (middle pregnancy), and 2,250 kcal/d and $85 \mathrm{~g} / \mathrm{d}$ (late pregnancy), respectively. The RNI of iodine was $230 \mathrm{\mu g} / \mathrm{L}$.

Due to technical limitations, table 2 is only available as a download in the Supplemental Files section.

Table 3. Energy, protein, iodine, and UIC in thyroid antibody positive vs. negative groups (median p25, p75) 


\begin{tabular}{|c|c|c|c|c|c|c|c|c|c|c|c|c|}
\hline & \multicolumn{3}{|l|}{ Pool } & \multicolumn{3}{|c|}{ Early pregnancy } & \multicolumn{3}{|c|}{ Middle pregnancy } & \multicolumn{3}{|c|}{ Late pregnancy } \\
\hline & + & - & $P$ & + & - & $P$ & + & - & $P$ & + & - & $P$ \\
\hline \multicolumn{13}{|l|}{ TPO-Ab } \\
\hline \multirow{2}{*}{$\begin{array}{l}\text { Energy intake } \\
\text { (kcal) }\end{array}$} & 1978.7 & 1988.8 & 0.751 & 1972.0 & 1887.2 & 0.555 & 1964.6 & 2054.5 & 0.986 & 2016.7 & 2069.6 & 0.284 \\
\hline & $\begin{array}{l}(1549.5 \square \\
2663.5)\end{array}$ & $\begin{array}{l}(1257.0 \otimes \\
2641.4)\end{array}$ & & $\begin{array}{l}(1569.0 \otimes \\
2458.2)\end{array}$ & $\begin{array}{l}(1451.4 \rrbracket \\
2524.8)\end{array}$ & & $\begin{array}{l}(1558.58 \\
2764.9)\end{array}$ & $\begin{array}{l}(1566.5 ه \\
2699.6)\end{array}$ & & $\begin{array}{l}(1425.0 \mathbb{} \\
2732.9)\end{array}$ & $\begin{array}{l}(1590.4 \rrbracket \\
2775.4)\end{array}$ & \\
\hline \multirow{2}{*}{$\begin{array}{l}\text { Total protein } \\
\text { intake }(\mathrm{g})\end{array}$} & 83.1 & 80.0 & 0.206 & 79.6 & 74.6 & 0.189 & 84.7 & 81.3 & 0.151 & 82.7 & 85.6 & 0.502 \\
\hline & $\begin{array}{l}(62.5 \rrbracket \\
114.0)\end{array}$ & $\begin{array}{l}(59.98 \\
112.9)\end{array}$ & & $\begin{array}{l}(58.4 \rrbracket \\
109.4)\end{array}$ & $\begin{array}{l}(56.5 \rrbracket \\
104.6)\end{array}$ & & $\begin{array}{l}(63.00 \\
119.0)\end{array}$ & $\begin{array}{l}(61.1 \otimes \\
113.6)\end{array}$ & & $\begin{array}{l}(64.4 \rrbracket \\
109.2)\end{array}$ & $\begin{array}{l}(63.8 \rrbracket \\
120.8)\end{array}$ & \\
\hline \multirow{2}{*}{$\begin{array}{l}\text { Animal } \\
\text { protein intake } \\
\text { (including } \\
\text { milk protein; } \\
\text { g) }\end{array}$} & 40.8 & 38.8 & 0.059 & 39.6 & 35.8 & 0.163 & 43.5 & 38.7 & 0.021 & 40.8 & 42.9 & 0.584 \\
\hline & $\begin{array}{l}(28.90 \\
61.7)\end{array}$ & $(27 \rrbracket 58.8)$ & & $\begin{array}{l}(27.4 区 \\
58.1)\end{array}$ & $\begin{array}{l}(24.98 \\
52.8)\end{array}$ & & $\begin{array}{l}(31.3 \rrbracket \\
64.6)\end{array}$ & $(27 \rrbracket 59)$ & & $\begin{array}{l}(30.5 \square \\
61.5)\end{array}$ & $\begin{array}{l}(29.8 \rrbracket \\
63.1)\end{array}$ & \\
\hline \multirow{2}{*}{$\begin{array}{l}\text { lodine intake } \\
(\mu \mathrm{g})\end{array}$} & 115.0 & 119.0 & 0.503 & 106.0 & 116.0 & 0.241 & 133.0 & 123.0 & 0.888 & 120.0 & 118.0 & 0.942 \\
\hline & $\begin{array}{l}(52.7 \rrbracket \\
192.2)\end{array}$ & $\begin{array}{l}(61.11 \\
197.1)\end{array}$ & & $\begin{array}{l}(45.6 \mathbb{8} \\
173.7)\end{array}$ & $\begin{array}{l}(58.9 \rrbracket \\
192.3)\end{array}$ & & $\begin{array}{l}(53.4 \rrbracket \\
208.7)\end{array}$ & $\begin{array}{l}(60.3 \rrbracket \\
199.3)\end{array}$ & & $\begin{array}{l}(59.6 \mathbb{6} \\
190.8)\end{array}$ & $\begin{array}{l}(64.2 \rrbracket \\
199.2)\end{array}$ & \\
\hline \multirow[t]{2}{*}{ UIC $(\mu \mathrm{g} / \mathrm{L})$} & 123.8 & 140.6 & 0.002 & 127.4 & 150.5 & 0.002 & 129.6 & 140.5 & 0.240 & 103.3 & 124.8 & 0.127 \\
\hline & $\begin{array}{l}(69.2 \bigotimes \\
202.0)\end{array}$ & $\begin{array}{l}(83.9 \rrbracket \\
221.3)\end{array}$ & & $\begin{array}{l}(72.2 \rrbracket \\
204.7)\end{array}$ & $\begin{array}{l}(89.4 \rrbracket \\
239.3)\end{array}$ & & $\begin{array}{l}(74.4 \bigotimes \\
196.5)\end{array}$ & $\begin{array}{l}(87.0 冈 \\
219.7)\end{array}$ & & $\begin{array}{l}(52.7 \rrbracket \\
202.4)\end{array}$ & $\begin{array}{l}(71.1 \rrbracket \\
200.2)\end{array}$ & \\
\hline \multicolumn{13}{|l|}{ TG-Ab } \\
\hline \multirow{2}{*}{$\begin{array}{l}\text { Energy intake } \\
\text { (kcal) }\end{array}$} & 1925.2 & 1994.7 & 0.194 & 1888.4 & 1897.0 & 0.466 & 1961.5 & 2054.5 & 0.688 & 2103.5 & 2055.7 & 0.641 \\
\hline & 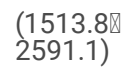 & $\begin{array}{l}(1531.80 \\
11092.3)\end{array}$ & & $\begin{array}{l}(1507.7 \rrbracket \\
2353.1)\end{array}$ & $\begin{array}{l}(1460.7 \rrbracket \\
2531.8)\end{array}$ & & $\begin{array}{l}(1575.7 \rrbracket \\
2698.8)\end{array}$ & $\begin{array}{l}(1565.2 \otimes \\
2706.0)\end{array}$ & & $\begin{array}{l}(1492.10 \\
2803.0)\end{array}$ & $\begin{array}{l}(1582.1 \rrbracket \\
2759.3)\end{array}$ & \\
\hline \multirow{2}{*}{$\begin{array}{l}\text { Total protein } \\
\text { intake }(\mathrm{g})\end{array}$} & 77.5 & 80.4 & 0.142 & 73.6 & 75.2 & 0.359 & 76.6 & 82.1 & 0.495 & 88.8 & 85.1 & 0.861 \\
\hline & $\begin{array}{l}(58.5 囚 \\
109.2)\end{array}$ & $\begin{array}{l}(60.4 \rrbracket \\
113.2)\end{array}$ & & $\begin{array}{l}(55.8 \bigotimes \\
100.6)\end{array}$ & $\begin{array}{l}(56.9 \rrbracket \\
105.6)\end{array}$ & & $\begin{array}{l}(59.6 \mathbb{6} \\
114.8)\end{array}$ & $\begin{array}{l}(61.7 囚 \\
114.1)\end{array}$ & & $\begin{array}{l}(62.5 \rrbracket \\
117.2)\end{array}$ & $\begin{array}{l}(64.0 \bigotimes \\
120.4)\end{array}$ & \\
\hline \multirow{2}{*}{$\begin{array}{l}\text { Animal } \\
\text { protein intake } \\
\text { (including } \\
\text { milk protein; } \\
\text { g) }\end{array}$} & 37.6 & 39.0 & 0.316 & 35.3 & 36.1 & 0.401 & 38.4 & 39.1 & 0.828 & 41.1 & 42.7 & 0.783 \\
\hline & $\begin{array}{l}(27.0 \otimes \\
57.0)\end{array}$ & $\begin{array}{l}(27.2 \otimes \\
59.0)\end{array}$ & & $\begin{array}{l}(24.6 \mathbb{} \\
52.4)\end{array}$ & $\begin{array}{l}(25.1 \rrbracket \\
53.3)\end{array}$ & & $\begin{array}{l}(28.7 \rrbracket \\
57.0)\end{array}$ & $\begin{array}{l}(27.10 \\
59.4)\end{array}$ & & $\begin{array}{l}(28.5 \square \\
63.9)\end{array}$ & 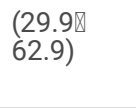 & \\
\hline \multirow{2}{*}{$\begin{array}{l}\text { lodine intake } \\
(\mu \mathrm{g})\end{array}$} & 118.0 & 119.0 & 0.542 & 106.0 & 115.0 & 0.076 & 138.0 & 123.0 & 0.261 & 128.0 & 118.0 & 0.934 \\
\hline & $\begin{array}{l}(56.9 \bigotimes \\
189.5)\end{array}$ & $\begin{array}{l}(60.5 \square \\
197.3)\end{array}$ & & $\begin{array}{l}(45.3 \bigotimes \\
170.4)\end{array}$ & $\begin{array}{l}(59.1 \rrbracket \\
193.6)\end{array}$ & & $\begin{array}{l}(77.0 \bigotimes \\
206.2)\end{array}$ & $\begin{array}{l}(58.3 \rrbracket \\
199.8)\end{array}$ & & $\begin{array}{l}(64.7 \rrbracket \\
191.2)\end{array}$ & $\begin{array}{l}(64.0 \rrbracket \\
197.5)\end{array}$ & \\
\hline \multirow[t]{2}{*}{ UIC $(\mu \mathrm{g} / \mathrm{L})$} & 132.4 & 139.9 & 0.205 & 132.8 & 150.0 & 0.009 & 146.2 & 138.8 & 0.630 & 115.4 & 123.7 & 0.684 \\
\hline & $\begin{array}{l}(73.4 \rrbracket \\
204.7)\end{array}$ & $\begin{array}{l}(82.6 \rrbracket \\
221.0)\end{array}$ & & $\begin{array}{l}(73.4 \rrbracket \\
198.4)\end{array}$ & $\begin{array}{l}(88.9 \varnothing \\
240.5)\end{array}$ & & $\begin{array}{l}(84.7 \rrbracket \\
219.8)\end{array}$ & $\begin{array}{l}(85.0 \bigotimes \\
217.3)\end{array}$ & & $\begin{array}{l}55.1 \otimes \\
213.0)\end{array}$ & $\begin{array}{l}(70.3 \rrbracket \\
199.5)\end{array}$ & \\
\hline \multicolumn{13}{|l|}{ TR-Ab } \\
\hline \multirow{2}{*}{$\begin{array}{l}\text { Energy intake } \\
\text { (kcal) }\end{array}$} & 1910.9 & 1994.7 & 0.169 & 1945.4 & 1889.3 & 0.470 & 1847.0 & 2058.8 & 0.095 & 1937.6 & 2072.7 & 0.347 \\
\hline & $\begin{array}{l}(1443.6) \\
2588.2)\end{array}$ & $\begin{array}{l}(1537.9 ه \\
2651.7)\end{array}$ & & $\begin{array}{l}(1501.9 ه \\
2493.6)\end{array}$ & $\begin{array}{l}(1459.98 \\
2523.4)\end{array}$ & & $\begin{array}{l}(1360.7 \rrbracket \\
2560.1)\end{array}$ & $\begin{array}{l}(1586.7 \rrbracket \\
2713 \llbracket 3)\end{array}$ & & $\begin{array}{l}(1447.9 \otimes \\
2691.3)\end{array}$ & $\begin{array}{l}(1591.38 \\
2783.6)\end{array}$ & \\
\hline \multirow{2}{*}{$\begin{array}{l}\text { Total protein } \\
\text { intake }(\mathrm{g})\end{array}$} & 71.9 & 81.1 & $<0.001$ & 75.7 & 75.0 & 0.966 & 66.0 & 82.4 & 0.004 & 64.7 & 86.6 & $<0.001$ \\
\hline & $\begin{array}{l}(52.8 \bigotimes \\
100.3)\end{array}$ & $\begin{array}{l}(60.98 \\
113.6)\end{array}$ & & $\begin{array}{l}(56.4 \rrbracket \\
97.7)\end{array}$ & $\begin{array}{l}(56.8 \rrbracket \\
106.3)\end{array}$ & & $\begin{array}{l}(51.7 \varnothing \\
99.8)\end{array}$ & $\begin{array}{l}(62.3 \rrbracket \\
114.3)\end{array}$ & & $\begin{array}{l}(48.6 \rrbracket \\
105.7)\end{array}$ & $\begin{array}{l}(65.4 \rrbracket \\
120.6)\end{array}$ & \\
\hline \multirow{2}{*}{$\begin{array}{l}\text { Animal } \\
\text { protein intake } \\
\text { (including } \\
\text { milk protein; } \\
\text { g) }\end{array}$} & 31.4 & $\begin{array}{l}39.5(27.5 \square \\
59.4)\end{array}$ & $<0.001$ & 32.7 & 36.5 & 0.545 & 30.2 & $39.8(27.5 \rrbracket$ & 0.028 & 31(22.7区 & 43.8 & $<0.001$ \\
\hline & $\begin{array}{l}(24.5 \rrbracket \\
49.4)\end{array}$ & & & $\begin{array}{l}(26.2 \rrbracket \\
49.3)\end{array}$ & $\begin{array}{l}(24.90 \\
53.8)\end{array}$ & & $\begin{array}{l}(24.2 \rrbracket \\
52.4)\end{array}$ & & & & $\begin{array}{l}(30.7 \nabla \\
63.2)\end{array}$ & \\
\hline \multirow{2}{*}{$\begin{array}{l}\text { lodine intake } \\
(\mu \mathrm{g})\end{array}$} & 130.0 & 118.0 & 0.114 & 115.0 & 114.0 & 0.829 & 138.0 & 123.0 & 0.716 & 148.0 & 117.0 & 0.001 \\
\hline & $\begin{array}{l}(59.1 \otimes \\
211.5)\end{array}$ & $\begin{array}{l}(60.1 \rrbracket \\
194.7)\end{array}$ & & $\begin{array}{l}(52.1 ه \\
183.2)\end{array}$ & $\begin{array}{l}(58.1 \rrbracket \\
193.5)\end{array}$ & & $\begin{array}{l}(45.6 \varnothing \\
211.6)\end{array}$ & $\begin{array}{l}(60.4 \bigotimes \\
199.2)\end{array}$ & & $\begin{array}{l}(93.08 \\
280.1)\end{array}$ & $\begin{array}{l}(62.8 \rrbracket \\
192.5)\end{array}$ & \\
\hline \multirow[t]{2}{*}{ UIC $(\mu \mathrm{g} / \mathrm{L})$} & 117.6 & 141.0 & 0.001 & 120.0 & 150.3 & 0.001 & 110.7 & 141.1 & 0.003 & 117.9 & 124.0 & 0.756 \\
\hline & $\begin{array}{l}(68.0 \bigotimes \\
205.1)\end{array}$ & $\begin{array}{l}(82.8 \rrbracket \\
221.0)\end{array}$ & & $\begin{array}{l}(68.1 区 \\
215.4)\end{array}$ & $\begin{array}{l}(89.1 \rrbracket \\
239.1)\end{array}$ & & $\begin{array}{l}(63.5 \bigotimes \\
172.3)\end{array}$ & $\begin{array}{l}(87.1 ه \\
219.8)\end{array}$ & & $\begin{array}{l}(69.1 区 \\
213.4)\end{array}$ & $\begin{array}{l}(69.5 \rrbracket \\
198.5)\end{array}$ & \\
\hline
\end{tabular}




\begin{tabular}{|c|c|c|c|c|c|c|c|c|c|c|c|c|}
\hline $\begin{array}{l}\text { Energy intake } \\
\text { (kcal) }\end{array}$ & $\begin{array}{l}1945.5 \\
(1493.7 \rrbracket \\
2638.6)\end{array}$ & $\begin{array}{l}2001.7 \\
(1538.3 \otimes \\
2647.3)\end{array}$ & 0.166 & $\begin{array}{l}1924.7 \\
(1516.4 \otimes \\
2466.3)\end{array}$ & $\begin{array}{l}2072.7 \\
(1451.4 \rrbracket \\
2534.6)\end{array}$ & 0.578 & $\begin{array}{l}1916.1 \\
(1496.9 \rrbracket \\
2656.7)\end{array}$ & $\begin{array}{l}2073.9 \\
(1587.10 \\
2712.7)\end{array}$ & 0.177 & $\begin{array}{l}1989.2 \\
(1457.7 \rrbracket \\
2803.6)\end{array}$ & $\begin{array}{l}1885.0 \\
(1606.1 \otimes \\
2758.6)\end{array}$ & 0.264 \\
\hline $\begin{array}{l}\text { Total protein } \\
\text { intake }(\mathrm{g})\end{array}$ & $\begin{array}{l}76.8 \\
(57.6 \otimes \\
108.7)\end{array}$ & $\begin{array}{l}80.9 \\
\\
(60.8 \otimes \\
113.5)\end{array}$ & 0.024 & $\begin{array}{l}76.8 \\
(57.1 \otimes \\
102.3)\end{array}$ & $\begin{array}{l}86.6 \\
(56.7 \rrbracket \\
106.4)\end{array}$ & 0.716 & $\begin{array}{l}76.3 \\
(58.1 \otimes \\
114.8)\end{array}$ & $\begin{array}{l}82.6 \\
(62.4 区 \\
114)\end{array}$ & 0.147 & $\begin{array}{l}77.2 \\
(58.5 \bigotimes \\
114.2)\end{array}$ & $\begin{array}{l}74.6 \\
(65.4 \rrbracket \\
121.1)\end{array}$ & 0.018 \\
\hline $\begin{array}{l}\text { Animal } \\
\text { protein intake } \\
\text { (including } \\
\text { milk protein) } \\
\text { (g) }\end{array}$ & $\begin{array}{l}36.6 \\
(26.1 \otimes \\
57.1)\end{array}$ & $\begin{array}{l}39.5 \\
\\
(27.5 \rrbracket \\
59.1)\end{array}$ & 0.061 & $\begin{array}{l}35.2 \\
(26.0 \mathrm{D} \\
54.5)\end{array}$ & $\begin{array}{l}43.9 \\
(24.98 \\
52.8)\end{array}$ & 0.892 & $\begin{array}{l}36.6 \\
(26.6 \rrbracket \\
58.5)\end{array}$ & $\begin{array}{l}39.6 \\
(27.4 \rrbracket \\
59.3)\end{array}$ & 0.666 & $\begin{array}{l}37.9 \\
(25.80 \\
61.7)\end{array}$ & $\begin{array}{l}36.2 \\
(30.7 \rrbracket \\
63.2)\end{array}$ & 0.012 \\
\hline $\begin{array}{l}\text { lodine intake } \\
(\mu \mathrm{g})\end{array}$ & $\begin{array}{l}119.0 \\
\\
(57.3 \bigotimes \\
198.7)\end{array}$ & 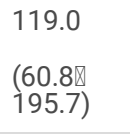 & 0.578 & $\begin{array}{l}109.0 \\
(50 \otimes \\
173.7)\end{array}$ & $\begin{array}{l}118.0 \\
(59.1 \rrbracket \\
195.7)\end{array}$ & 0.254 & $\begin{array}{l}138.0 \\
(63.6 \rrbracket \\
209.1)\end{array}$ & 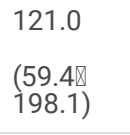 & 0.217 & $\begin{array}{l}126.0 \\
(65.7 \rrbracket \\
213.9)\end{array}$ & $\begin{array}{l}117.0 \\
(63.6 \rrbracket \\
194.4)\end{array}$ & 0.172 \\
\hline UIC $(\mu \mathrm{g} / \mathrm{L})$ & $\begin{array}{l}123.0 \\
(70.6 \rrbracket \\
204.4)\end{array}$ & $\begin{array}{l}142.2 \\
(85.2 \otimes \\
222.5)\end{array}$ & $<0.001$ & $\begin{array}{l}126.6 \\
(71.6 \rrbracket \\
208.7)\end{array}$ & $\begin{array}{l}154.1 \\
(91.8 \otimes \\
246.1)\end{array}$ & $<0.001$ & $\begin{array}{l}126.4 \\
(75.8 \rrbracket \\
198.0)\end{array}$ & $\begin{array}{l}142.0 \\
(88.0 \otimes \\
220.6)\end{array}$ & 0.043 & $\begin{array}{l}113.7 \\
(63.0 \rrbracket \\
206.5)\end{array}$ & $\begin{array}{l}126.0 \\
(71.4 \rrbracket \\
198.4)\end{array}$ & 0.392 \\
\hline
\end{tabular}

Table 4. Factors associated with positive thyroid antibody 


\begin{tabular}{|c|c|c|c|c|c|c|c|c|c|c|c|c|c|c|c|}
\hline & \multicolumn{4}{|l|}{ TPO-Ab } & \multicolumn{4}{|l|}{ TG-Ab } & \multicolumn{4}{|l|}{ TR-Ab } & \multicolumn{3}{|c|}{ TPO-Ab/TG-Ab/TR-Ab } \\
\hline & $\beta$ & Coeff. & $\begin{array}{l}95 \% \\
\mathrm{Cl}\end{array}$ & $P$ & $\beta$ & Coeff. & $\begin{array}{l}95 \% \\
\mathrm{Cl}\end{array}$ & $P$ & $\beta$ & Coeff. & $\begin{array}{l}95 \% \\
\mathrm{Cl}\end{array}$ & $P$ & $\beta$ & Coeff. & $\begin{array}{l}95 \% \\
\mathrm{Cl}\end{array}$ \\
\hline \multicolumn{16}{|l|}{ Age } \\
\hline$<35 y$ & \multicolumn{4}{|c|}{ reference } & \multicolumn{4}{|c|}{ reference } & \multicolumn{4}{|c|}{ reference } & \multicolumn{3}{|c|}{ reference } \\
\hline$\geq 35 y$ & 0.106 & l & / & 0.442 & 0.149 & / & / & 0.294 & -0.115 & l & / & 0.480 & 0.019 & / & / \\
\hline \multicolumn{16}{|l|}{$\begin{array}{l}\text { Educational } \\
\text { level }\end{array}$} \\
\hline$\leq 9 y$ & \multicolumn{4}{|c|}{ reference } & \multicolumn{4}{|c|}{ reference } & \multicolumn{4}{|c|}{ reference } & \multicolumn{3}{|c|}{ reference } \\
\hline $\begin{array}{l}\text { Senior high } \\
\text { school and } \\
\text { college }\end{array}$ & 0.117 & l & I & 0.474 & -0.012 & / & I & 0.937 & -0.588 & 0.555 & $\begin{array}{l}0.418- \\
0.737\end{array}$ & $<0.001$ & -0.234 & 0.792 & $\begin{array}{l}0.64 \\
0.98\end{array}$ \\
\hline $\begin{array}{l}\text { Bachelor } \\
\text { degree and } \\
\text { above }\end{array}$ & 0.256 & I & I & 0.137 & 0.024 & I & I & 0.888 & -1.044 & 0.352 & $\begin{array}{l}0.253- \\
0.49\end{array}$ & $<0.001$ & -0.343 & 0.710 & $\begin{array}{l}0.56 \\
0.89\end{array}$ \\
\hline \multicolumn{16}{|l|}{$\begin{array}{l}\text { Occupational } \\
\text { status }\end{array}$} \\
\hline $\begin{array}{l}\text { Physical } \\
\text { work }\end{array}$ & \multicolumn{4}{|c|}{ reference } & \multicolumn{4}{|c|}{ reference } & \multicolumn{4}{|c|}{ reference } & \multicolumn{3}{|c|}{ reference } \\
\hline Mental work & 0.225 & 1.253 & $\begin{array}{l}1.029- \\
1.526\end{array}$ & 0.025 & 0.213 & 1.237 & $\begin{array}{l}1.009- \\
1.517\end{array}$ & 0.041 & 0.099 & I & I & 0.385 & 0.178 & 1.195 & $\begin{array}{l}1.02 \\
1.39\end{array}$ \\
\hline \multicolumn{16}{|c|}{ Family income last year, YUAN } \\
\hline$<100,000$ & \multicolumn{4}{|c|}{ reference } & \multicolumn{4}{|c|}{ reference } & \multicolumn{4}{|c|}{ reference } & \multicolumn{3}{|c|}{ reference } \\
\hline $\begin{array}{l}100,000- \\
200,000\end{array}$ & -0.004 & l & I & 0.980 & -0.096 & l & I & 0.512 & -0.041 & I & I & 0.776 & -0.122 & I & I \\
\hline$\geq 200,000$ & 0.001 & I & I & 0.995 & -0.303 & I & I & 0.058 & -0.289 & I & I & 0.085 & -0.209 & I & I \\
\hline \multicolumn{16}{|l|}{$\begin{array}{l}\text { Pregnancy } \\
\text { stage }\end{array}$} \\
\hline $\begin{array}{l}\text { Early } \\
\text { pregnancy }\end{array}$ & \multicolumn{4}{|c|}{ reference } & referenc & & & & referenc & & & & referen & & \\
\hline $\begin{array}{l}\text { Middle } \\
\text { pregnancy }\end{array}$ & -0.089 & I & I & 0.448 & -0.382 & 0.682 & $\begin{array}{l}0.538- \\
0.865\end{array}$ & 0.002 & -0.799 & 0.450 & $\begin{array}{l}0.344- \\
0.587\end{array}$ & $<0.001$ & -0.348 & 0.706 & $\begin{array}{l}0.59 \\
0.84\end{array}$ \\
\hline $\begin{array}{l}\text { Late } \\
\text { pregnancy }\end{array}$ & -0.198 & I & I & 0.112 & -0.509 & 0.601 & $\begin{array}{l}0.465- \\
0.778\end{array}$ & $<0.001$ & -0.580 & 0.560 & $\begin{array}{l}0.429- \\
0.731\end{array}$ & $<0.001$ & -0.299 & 0.742 & $\begin{array}{l}0.62 \\
0.88\end{array}$ \\
\hline $\begin{array}{l}\text { Energy } \\
\text { intake }\end{array}$ & & & & & & & & & & & & & & & \\
\hline $\begin{array}{l}\text { Bottom third } \\
(<1,683.6 \\
\mathrm{kcal} / \mathrm{d})\end{array}$ & referenc & & & & referenc & & & & referenc & & & & referen & & \\
\hline $\begin{array}{l}\text { Middle third } \\
(1,683.6- \\
2,371.2 \\
\mathrm{kcal} / \mathrm{d})\end{array}$ & -0.169 & I & I & 0.234 & -0.078 & I & I & 0.596 & 0.200 & I & I & 0.199 & -0.061 & I & I \\
\hline $\begin{array}{l}\text { Top third (> } \\
2,371.2 \\
\mathrm{kcal} / \mathrm{d})\end{array}$ & -0.259 & I & I & 0.102 & -0.011 & I & I & 0.947 & 0.300 & I & I & 0.091 & -0.045 & I & I \\
\hline Animal proteir & including & milk pro & ein) & & & & & & & & & & & & \\
\hline $\begin{array}{l}\text { Bottom third } \\
(<30.9 \mathrm{~g} / \mathrm{d})\end{array}$ & referenc & & & & referenc & & & & referenc & & & & referenc & & \\
\hline $\begin{array}{l}\text { Middle third } \\
\text { (30.9-50.3 } \\
\text { g/d) }\end{array}$ & 0.204 & I & I & 0.155 & -0.120 & I & I & 0.406 & -0.582 & 0.559 & $\begin{array}{l}0.415- \\
0.752\end{array}$ & $<0.001$ & -0.202 & 0.817 & $\begin{array}{l}0.68 \\
0.97\end{array}$ \\
\hline $\begin{array}{l}\text { The top third } \\
(>50.3 \mathrm{~g} / \mathrm{d})\end{array}$ & 0.179 & I & I & 0.219 & -0.105 & I & l & 0.600 & -0.901 & 0.406 & $\begin{array}{l}0.266- \\
0.621\end{array}$ & $<0.001$ & -0.217 & 0.805 & $\begin{array}{l}0.67 \\
0.96\end{array}$ \\
\hline Percentage of & nimal pre & tein fron & total prot & & & & & & & & & & & & \\
\hline $\begin{array}{l}\text { Bottom third } \\
(<45 \%)\end{array}$ & referenc & & & & referenc & & & & referenc & & & & referen & & \\
\hline Middle third & -0.122 & I & I & 0.389 & -0.160 & I & I & 0.274 & 0.205 & I & I & 0.180 & -0.044 & I & I \\
\hline
\end{tabular}




\begin{tabular}{|c|c|c|c|c|c|c|c|c|c|c|c|c|c|c|c|}
\hline $\begin{array}{l}\text { Top third (> } \\
54 \%)\end{array}$ & -0.090 & I & I & 0.580 & 0.037 & / & / & 0.824 & 0.231 & I & I & 0.201 & -0.007 & / & / \\
\hline \multicolumn{16}{|l|}{ lodine intake } \\
\hline $\begin{array}{l}\text { Bottom third } \\
(<78.7 \mu \mathrm{g} / \mathrm{d})\end{array}$ & \multicolumn{4}{|c|}{ reference } & \multicolumn{4}{|c|}{ reference } & \multicolumn{4}{|c|}{ reference } & \multicolumn{3}{|c|}{ reference } \\
\hline $\begin{array}{l}\text { Middle third } \\
(78.7-162.9 \\
\mu \mathrm{g} / \mathrm{d})\end{array}$ & -0.073 & I & I & 0.619 & -0.075 & I & I & 0.623 & 0.318 & I & I & 0.075 & 0.084 & / & / \\
\hline $\begin{array}{l}\text { Top third (> } \\
162.9 \mu \mathrm{g} / \mathrm{d})\end{array}$ & 0.007 & I & I & 0.971 & 0.032 & I & / & 0.867 & 0.385 & I & I & 0.073 & 0.165 & I & I \\
\hline \multicolumn{16}{|l|}{ Median of UIC } \\
\hline $\begin{array}{l}\text { Adequate } \\
\text { iodine group }\end{array}$ & \multicolumn{4}{|c|}{ Reference } & \multicolumn{4}{|c|}{ reference } & \multicolumn{2}{|c|}{ reference } & & & \multicolumn{2}{|c|}{ reference } & \\
\hline $\begin{array}{l}\text { Insufficient } \\
\text { iodine group }\end{array}$ & 0.246 & 1.279 & $\begin{array}{l}1.009- \\
1.621\end{array}$ & 0.042 & 0.110 & / & / & 0.374 & 0.377 & 1.457 & $\begin{array}{l}1.119- \\
1.899\end{array}$ & 0.005 & 0.286 & 1.331 & $\begin{array}{l}1.11 \\
1.58\end{array}$ \\
\hline $\begin{array}{l}\text { Excessive } \\
\text { iodine group }\end{array}$ & 0.037 & 1.038 & $\begin{array}{l}0.764- \\
1.409\end{array}$ & 0.813 & -0.021 & I & / & 0.892 & -0.066 & 0.936 & $\begin{array}{l}0.657- \\
1.333\end{array}$ & 0.714 & 0.009 & 1.009 & $\begin{array}{l}0.80 \\
1.26\end{array}$ \\
\hline \multicolumn{16}{|c|}{ Percentage of energy from fat } \\
\hline$\leq 30 \%$ & \multicolumn{4}{|c|}{ reference } & \multicolumn{4}{|c|}{ reference } & \multicolumn{4}{|c|}{ reference } & \multicolumn{3}{|c|}{ reference } \\
\hline$>30 \%$ & 0.236 & 1.301 & $\begin{array}{l}1.013- \\
1.671\end{array}$ & 0.039 & 0.221 & 1.285 & $\begin{array}{l}1.004- \\
1.581\end{array}$ & 0.046 & 0.117 & I & / & 0.403 & 0.159 & / & / \\
\hline
\end{tabular}

\section{Supplementary Files}

This is a list of supplementary files associated with this preprint. Click to download.

- Table2.docx 